\title{
Hypergonadotropic hypogonadism: looking beyond ovarian senescence
}

\author{
Richa Vatsa ${ }^{1 *}$, Vanita Suri ${ }^{2}$, Neelam Choudhary ${ }^{2}$, Aashima Arora ${ }^{2}$, Shruti Sharma ${ }^{2}$
}

\author{
${ }^{1}$ Department of Obstetrics and Gynaecology, AIIMS, New Delhi, India \\ ${ }^{2}$ Department of Obstetrics and Gynaecology, PGIMER, Chandigarh, Punjab, India
}

Received: 26 November 2020

Accepted: 04 January 2021

\section{*Correspondence:}

Dr. Richa Vatsa,

E-mail: dr.richavatsa@gmail.com

Copyright: $\odot$ the author(s), publisher and licensee Medip Academy. This is an open-access article distributed under the terms of the Creative Commons Attribution Non-Commercial License, which permits unrestricted non-commercial use, distribution, and reproduction in any medium, provided the original work is properly cited.

\begin{abstract}
Gonadotropin resistant ovary syndrome (GROS) is a rare cause of primary infertility where ovarian reserve is present but they fail to respond to gonadotropin stimulation. This condition can be easily confused with premature ovarian insufficiency (POI) if thorough workup is not done as in both the cases serum FSH is high, but ovarian reserve is normal in GROS and low or absent in POI. So, we are presenting this case of GROS. A 28-year-old lady presented with oligomenorrhoea since menarche and primary infertility. On workup her serum FSH and LH levels were markedly elevated, serum estradiol was normal. Markers of ovarian reserve, ante Mullerian hormones (AMH) and antral follicle count (AFC), were normal. Her autoantibody assay was also normal. She did not respond to stimulation with high doses of gonadotropins (uHMG). Hypergonadotropic hypogonadism is not always POI. We should not miss diagnosis of GROS where it is possible to have own biological child by in vitro maturation of immature oocytes, whereas in POI donor oocyte is the only fertility option.
\end{abstract}

Keywords: Gonadotropin resistant ovary syndrome, Infertility, In vitro maturation

\section{INTRODUCTION}

GROS also known as savage syndrome is a rare cause of infertility characterized by hypergonadotropic hypogonadism. ${ }^{1}$ Infertility is a common complaint of woman presenting with GROS, and fertility aspects are poor in these patients.

This condition can be misdiagnosed easily as POI without complete infertility workup. Measurement of markers of ovarian reserve like $\mathrm{AMH}$ and $\mathrm{AFC}$ can differentiate these two conditions. In vitro maturation (IVM) of oocyte has started emerging as treatment modality to have their own biological child. ${ }^{2,3}$ Whereas there is no hope of pregnancy with own oocytes in women with POI. So, this condition should be differentiated from GROS. Here we are presenting a case of GROS who came to us with infertility.

\section{CASE REPORT}

A 28-year-old lady presented to with complains of oligomenorrhoea since menarche and primary infertility for 10 years. Menstrual cycles were of 40-60 days duration There were no symptoms, hot flushes or vaginal dryness, related to menopause. She had a body mass index (BMI) of 21.6, no significant finding in general physical examination and gynaecological examination. Her sexual maturity rating was $\mathrm{A}+\mathrm{B}_{4} \mathrm{P}_{4}$. On workup her serum FSH and LH levels were markedly elevated, serum estradiol was normal. Markers of ovarian reserve, AMH and AFC (Figure 1), were normal. Her autoantibody assay, which included anti thyroid peroxidise (anti TPO), anti-transglutaminase (anti-tTG), antinuclear antibody (ANA); was also normal. Investigations are summarized in Table 1. Anti-gonadotropin levels and anti-adrenal antibodies could not be measured due to non-availability of these diagnostic test. Other infertility workups, 
husband semen analysis and hysterosalpingography, were normal.

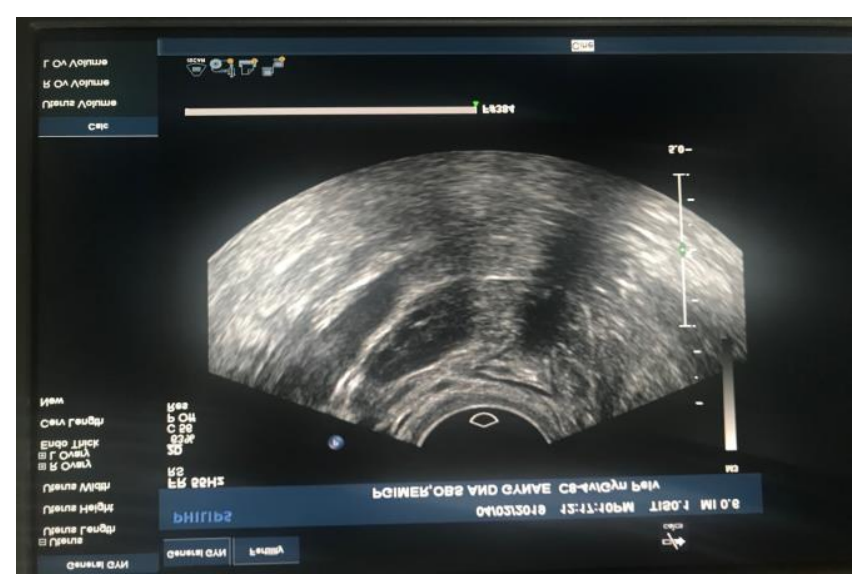

Figure 1: Transvaginal ultrasonography of ovary with antral follicles.

Table 1: Result of various investigations done.

\begin{tabular}{|c|c|c|c|c|}
\hline \multirow{2}{*}{ Test } & \multicolumn{3}{|l|}{ Value } & \multirow{2}{*}{$\begin{array}{l}\text { Normal } \\
\text { value }\end{array}$} \\
\hline & 2013 & 2017 & 2018 & \\
\hline $\begin{array}{l}\text { D3 FSH } \\
\text { (IU/L) }\end{array}$ & 30.66 & 62.42 & 55.35 & $3.5-12.5$ \\
\hline $\begin{array}{l}\text { D3 LH } \\
(\mathrm{mIU} / \mathrm{ml})\end{array}$ & 30.56 & 16.69 & 40.67 & $2.2-12.6$ \\
\hline $\begin{array}{l}\text { AMH } \\
(\mathbf{n g} / \mathbf{m l})\end{array}$ & 10.9 & & 4.78 & $1.0-3.5$ \\
\hline $\begin{array}{l}\text { Estradiol } \\
\text { (pg/ml) }\end{array}$ & & & 72.64 & $12.5-166$ \\
\hline $\begin{array}{l}\text { Testosterone } \\
(\mathrm{nmol} / \mathrm{L})\end{array}$ & & & 1.6 & $0.2-2.9$ \\
\hline $\begin{array}{l}\text { TSH } \\
(\mu I U / m l)\end{array}$ & & & 2.73 & $0.5-4.5$ \\
\hline $\begin{array}{l}\text { Prolactin } \\
(\mu \mathrm{g} / \mathrm{L})\end{array}$ & & & 12.8 & $4.7-23.3$ \\
\hline ANA & & & Negat & \\
\hline $\begin{array}{l}\text { Anti TPO } \\
(I U / m l)\end{array}$ & & & 11.81 & \\
\hline $\begin{array}{l}\text { IgA-tTG } \\
(\mathbf{U} / \mathbf{m l})\end{array}$ & & & $<0.1$ & $<7$ \\
\hline MRI brain & & Norma & study ( & \\
\hline Karyotype & & $46 X X$ & & \\
\hline
\end{tabular}

After complete infertility evaluation patient, with a possible diagnosis of GROS, patient was started on ovarian stimulation with highly purified urinary human menopausal gonadotropin. However, after administration of 10 days in the dose 150 IU there was no follicular recruitment. Dose was increased to $225 \mathrm{IU} /$ day for 8 days, but there was no response after total duration of 18 days and a dose of 3300 IU. In next cycle we planned her stimulation after down regulation with gonadotropin releasing hormone agonist (GnRHa) depot (leuprolide acetate $3.75 \mathrm{mg}$ IM), again after 15 days of stimulation, starting with $150 \mathrm{IU}$ and increasing the dose up to $300 \mathrm{IU}$ (total dose $3375 \mathrm{IU}$ ), there was no follicular recruitment and cycle abandoned. After two failed cycles of gonadotropin stimulation, we referred her to centre with facility for in vitro maturation but patient refused any further treatment due to financial constraints.

\section{DISCUSSION}

GROS is well known entity and rare cause of infertility. Patients present with oligomenorrhoea or amenorrhoea and workup show hypergonadotropic hypogonadism. These patients may have mutation in FSH receptor. ${ }^{4}$ Total of 17 inactivating mutations have been identified. ${ }^{5}$ Case report has described galactosemia and antigonadotropin antibodies $^{6}$ also as a cause of gonadotropin resistance. The condition can be easily confused with POI as both present with raised FSH. One study showed that as many as $11-20 \%$ patients with diagnosis of POI may turn out to be GROS on detailed workup. ${ }^{7}$ Older times ovarian biopsy was used to diagnose ROS, showing various primordial follicles and absence of graffian follicles. With good quality ultrasound, AFCs helps in noninvasive diagnosis of this condition. ${ }^{8}$ Further $\mathrm{AMH}$ and inhibin B can also differentiate these conditions. ${ }^{9}$ These markers of ovarian reserve will be normal in GROS but low in POI. It is important to differentiate these two conditions as pregnancy with self-oocyte is possible in former condition not in later one. Follicles often fail to respond when stimulated with gonadotropin., $2,10,11$ Clinicians have tried suppression of FSH and LH with oral contraceptive pills (OCPs) and GnRGa followed by gonadotropin stimulation but without success in most cases. ${ }^{2,10,11}$ Rogenhofer et al used suppression with OCP and GnRHa followed by gonadotropin stimulation (recombinant FSH and highly purified urinary HMG) in a patient of GROS due to antigonadotropin antibody followed by IVF, resulting in successful live birth. ${ }^{6}$ Authors hypothesized that down regulation of endogenous gonadotrophins for three cycles might have contributed in desensitization of autoantibodies and up regulation of follicular FSH receptors. However, titers of gonoadotrophins were not measured to prove this point. The pregnancy is possible in GROS by IVM of immature oocytes followed by IVF and intracytoplasmic sperm injection (ICSI) cycle. First birth in woman with ROS by this modality was reported by Grynberg et al in 2013. ${ }^{10}$ Further more cases of live birth in these patients with IVM have been reported till date. ${ }^{2,3}$ Galvão et al performed 24 IVM cycles in 9 patients with resistant ovary syndrome. ${ }^{3}$ Average of $11.5 \pm 10.4$ cumulus oocyte complexes (COC) was retrieved, and IVM resulted in 3.4 \pm 3.1 mature oocytes. Eight patients became pregnant after ICSI and transfer of 23 cleavage stage embryos, resulting in five healthy live births, live birth rate was $16.7 \%$ per started cycle and $33.3 \%$ per patient. ${ }^{3}$ So, pregnancy is possible in these patients with IVM of selfoocytes followed by IVF/ICSI should be considered first line infertility treatment before embarking for donor oocyte IVF. 
Due to rarity of this condition, there is lack of evidencebased management for GROS. We do not know why gonadotropin stimulation after suppression with OCPs and GnRHa was effective in some cases but ineffective in others. $^{2,5,10,11}$ Further mechanism needs to be established by which in vitro gonadotropins becomes effective on oocytes, same was not effective in vivo. Studies are needed to get these answers.

\section{CONCLUSION}

Hypergonadotropic hypogonadism does not mean POI always. Clinician should do complete work up of these patients who present with infertility. Markers of ovarian reserve will differentiate these two conditions.

Funding: No funding sources

Conflict of interest: None declared

Ethical approval: Not required

\section{REFERENCES}

1. Jones GS, De Moraes-Ruehsen M. A new syndrome of amenorrhae in association with hypergonadotropism and apparently normal ovarian follicular apparatus. Am J Obstet Gynecol. 1969;104:597-600.

2. Flageole C, Toufaily C, Bernard DJ, Ates S, Blais V, Chénier $\mathrm{S}$ et al. Successful in vitro maturation of oocytes in a woman with gonadotropin-resistant ovary syndrome associated with a novel combination of FSH receptor gene variants: a case report. J Assisted Reprod Genet. 2019;36(3):425-32.

3. Galvão A, Segers I, Smitz J, Tournaye I, Vos MD. In vitro maturation (IVM) of oocytes in patients with resistant ovary syndrome and in patients with repeated deficient oocyte maturation. J Assisted Reprod Genet. 2018;35:2161-71.
4. Desai SS, Roy BS, Mahale SD. Mutations and polymorphisms in FSH receptor: functional implications in human reproduction. Reprod Camb Engl. 2013;146(6):R235-48.

5. He WB, Du J, Yang XW, Li W, Tang WL, Dai C et al. Novel inactivating mutations in the FSH receptor cause premature ovarian insufficiency with resistant ovary syndrome. Reprod Biomed Online. 2019;38(3):397-406.

6. Rogenhofer N, Pavlik R, Jeschke U, Wypior G, Ochsenk€uhn R, Thaler CJ. Effective ovarian stimulation in a patient with resistant ovary syndrome and antigonadotrophin antibodies. Am J Reprod Immunol. 2015;73:185-91.

7. Aiman J, Smentek C. Premature ovarian failure. Obstet Gynecol. 1985;66:9-14.

8. Mehta AE, Matwijiw I, Lyons EA, Faiman C. Noninvasive diagnosis of resistant ovary syndrome by ultrasonography. Fertility Sterility. 1992;57(1):56-61.

9. Dewailly D, Andersen CY, Balen A, Broekmans F, Dilaver N, Fanchin R et al. The physiology and clinical utility of anti-Mullerian hormone in women. Hum Reprod Update. 2014;20(3):370-85.

10. Grynberg M, Peltoketo H, Christin-Maitre S, Poulain M, Bouchard P, Fanchin R. First birth achieved after in vitro maturation of oocytes from a woman endowed with multiple antral follicles unresponsive to follicle-stimulating hormone. J Clin Endocrinol Metab. 2013;98:4493-8.

11. Li Y, Pan P, Yuan P, Qiu Q, Yang D. Successful live birth in a woman with resistant ovary syndrome following in vitro maturation of oocytes. J Ovarian Res. 2016;9:54.

Cite this article as: Vatsa R, Suri V, Choudhary N, Arora A. Hypergonadotropic hypogonadism: looking beyond ovarian senescence. Int J Reprod Contracept Obstet Gynecol 2021;10:791-3. 